\title{
Editorial
}

\section{Introduction: the instability of intellectual property}

For the past seven years, the goal of The International Society for the History and Theory of Intellectual Property (ISHTIP: http://www.ishtip.org) has been to "promote, coordinate, and disseminate critical inquiry into IP', and 'to re-frame - to broaden and deepen current IP debate'. The primary venue where ISHTIP pursues this objective is during its annual workshop, a meeting-place for scholars whose work in various ways relates to intellectual property and a forum for discussion benefiting the interdisciplinary dialogue that ISHTIP seeks to stimulate.

In 2014, we had the pleasure of organizing the sixth annual ISHTIP workshop at Uppsala University, Sweden. It was thus our responsibility to come up with a workshop theme that would be broad and inclusive enough to attract interesting and creative proposals but that would steer away from being too broad and in danger of losing all cohesion. We settled on The Instability of Intellectual Property, and defined it, not so much as a negative and unstable space, but as a dynamic that captured the way in which intellectual property moves and travels.

By emphasizing instability we wanted to include a broad variety of historical and/or contemporary topics that explored interdisciplinary and international aspects of intellectual property, engaging with the diversity and plurality of legal and linguistic traditions. Instability could refer to the way intellectual property law seeks to pin down a legal regime for increasingly unstable works. Instability could refer to the many processes of cultural and legal translation and transculturation involved in flows of culture. Instability could also, or so we envisioned, refer to the very 'doing' of intellectual property research itself, the interdisciplinary challenges of moving across and beyond disciplines.

The six contributions in this special issue of Queen Mary Journal of Intellectual Property were all part of the 2014 ISHTIP workshop, and we want to thank Johanna Gibson for her generosity in allowing us to bring them and ISHTIP to the QMJIP.

In his article 'Tactical destabilization for economic justice: the first phase of the 19842004 rhythm \& blues royalty reform movement', Matt Stahl discusses how a generation of rhythm \& blues musicians, who were systematically exploited by the record industry throughout the 1940s to the 1970s, came to be retroactively recompensed in the 1980s. It is an intriguing story about racialized injustices within the music industry, where mostly coloured musicians where suffering from lifelong debts to the record companies as the productions costs they had to cover far exceeded their minimal royalties. In the 1980s this resulted in the emergence of a rhythm \& blues royalty reform movement that, through active campaigning and relentless legal processes, finally made the record companies wipe out the debts of numerous well-known artists. Stahl's article is an excellent example of how the law is, in practice, always situated in and subject to other social and political structures. As these structures and practices change over time, this also affects the possibilities of making legal claims. Stahl's cases thus expose how the concepts of authorship 
and intellectual property are unstable by definition. Regardless of lawyers' and legislators' attempts to create clear legal definitions and boundaries, the law is always subject to tensions from outside of its own particular field of legislation. This is why we need interdisciplinary perspectives to fully grasp how intellectual property rights and authorship are enacted and practised.

A very different story of performers and record companies, Rasmus Fleischer's 'Protecting the musicians and/or the record industry? On the history of "neighbouring rights" and the role of Fascist Italy', weaves together a history of twentieth-century music copyright with a history of the intellectual property interventions of the Italian Fascist government during the 1930s. Fleischer's overall ambition is to contribute to the understanding of the historical development of neighbouring rights by concentrating on the emerging regulation of 'secondary use' of musical recordings. Italy played a particularly important role in this development. Fleischer outlines the Italian initiatives as pro-record industry in contrast to less successful parallel alternatives from Scandinavia that were less amenable to industry interest. He takes us into the politicized atmosphere of the International Labour Organization and the Berne Convention, showing how the interests of the record industry prevailed over the interests of musicians. Ultimately, Fleischer's article shows the intersection between law and politics as a domain of instability.

As one of the few contributions on patents at the 2014 workshop, Nicolas Chachereau's article 'How to patent a chemical? The instability of a new type of intellectual property (Switzerland 1888-1907)' highlights 'unstable' products: chemistry. He tells the complex story of the inclusion of patents for chemicals under Swiss patent law at the turn of the century, partly by a legal transplant of German law. The object itself - chemicals with an inherently 'liquid' nature - can serve as a metaphor for the instability and ambiguities involved: the difficulties in finding a clear scope of the patent; protecting the process or the product, or both? Including what in the process and in the product? How can innovation and competitiveness be balanced in a field where thousands of substances are involved in a prospective patent? Many of the substances were unknown at the time as chemistry was in its early days. Too broad patents or patents with unclear borders risked 'locking in' new substances. The German chemical industry had a dominating position in the world, and transplanting German law was central in the Swiss debates. But what would the consequences be when German law passed the Swiss border? Patent law, Chachereau notes, was a political field where it was totally legitimate to adopt provisions in the best interests of the national industry. But what were the best interests of the Swiss chemical industry? The Swiss dyestuff, electrochemical and pharmaceutical industries had diverging agendas, moreover their positions changed during the legislative process. Adopting a historical perspective, Chachereau neatly contextualizes some of the dilemmas of instability in intellectual property law.

Michael Birnhack's contribution 'Judicial snapshots and fair use theory' digs even deeper into the concept of legal transplants. His article explores the instabilities emerging when a momentary image of a legal situation travels from one jurisdiction to another in a decontextualized and undertheorized way, 'a judicial snapshot'. Birnhack unfolds the gradual transformation in Israeli law from the concept of 'fair dealings' to the concept of 'fair use', starting in Israeli courts applying American justifications for 'fair use' - from a certain point in time - within the British legal structure of 'fair dealings', ignoring the further development of the concept in American courts. The article describes the mysterious ways intellectual property law crossed borders and legal cultures by 'copy and paste', creating instability through the lack of adaptation to the local context. Birnhack argues that a theoretical disentanglement of the concept of fair use 
before introducing it in Israeli courts could have saved them from ending up in a 'jurisprudential muddle'.

A similar 'muddle' can perhaps be identified in 'Public architectural art and its spirits of instability', Aura Bertoni and Maria Lillà Montagnani's contribution on the relationship between copyright law and architecture. Making a distinction between public architectural art (buildings and structures that are both an expression of architects' signature creativity and style and have a utilitarian purpose) and public works of fine art (artworks permanently sited in public spaces), the authors note that the first category has largely been neglected in legal scholarship. Partly in response to this lacuna, Bertoni and Montagnani argue that public architectural art is in fact a particularly rewarding field of study for intellectual property scholarship. The high degree of jurisdictional instability that results from how public architectural art is treated in various national laws poses a challenge in itself, compounded even further when the vested interests from a number of different stakeholders are taken into account. As Bertoni and Montagnani take us through the unpredictability and variability of the entities 'public', 'architectural' and 'art', they reveal just how complex the interplay is between the law and public space.

Finally, Debora Halbert and Jake Dunagan's article 'Intellectual property for the neurocentric age: towards a neuropolitics of IP' takes the concept of instability to its most radical interpretation, since it points to the fundamental instability of the human subject that is often taken for granted as the firm ground on which both law and art rest. If the rapid changes in our technological and social living conditions affect our cognitive existence - how the brain and the human subject work - then recent developments in brain science change our understanding of these very processes. Drawing on Carl Zimmer, Halbert and Dunagan describes this as a 'neurocentric age' characterized by how neuroscience and a deeper understanding of the human mind as embedded in various technological and social structures form how we can think about law, politics and social sciences. This also affects how knowledge and immaterial resources are produced through crowdsourcing and other kinds of collaborative, collective thinking that are more in line with the understanding of human minds as mutually interconnected. The question that Halbert and Dunagan raise is how intellectual property law can respond to a changing understanding of its very precondition: the autonomy of the creative mind.

Together, these six articles show not only the varied instability topics represented at the 2014 workshop; they also demonstrate the international and interdisciplinary scope of ISHTIP, with contributors from Sweden, Canada, the USA, Italy, Switzerland and Israel, working in disciplines as diverse as political science, law, media and communication studies, history and economic history.

However, while we had an impressively diverse response to the instability call, our invitation to think about the term as part of the interdisciplinary challenges of intellectual property scholarship was not embraced with the same enthusiasm. The multidisciplinarity of the individual articles bears witness to how ISHTIP has established itself as the most prominent forum for a discussion of intellectual property that transcends conventional disciplinary borders. We wanted to encourage a self-reflexive discussion on this particular field of research, as it navigates and expands across and beyond disciplinary traditions, and initiate a dialogue that deployed a meta-perspective on the theme by looking at intellectual property as a field of study and its disciplinarily unstable (or possible stable interdisciplinarity) position within academia. We did so by inviting a group of scholars to a round-table discussion. From Australia, Dan Hunter (Swinburne University of Technology), from Denmark, Stina Teilmann-Lock (University of Southern Denmark), from France, 
Gabriel Galvez-Behar (Université Lille 3) and from the US, Debora Halbert (University of Hawaii at Manoa) participated. We are grateful to them for joining this discussion and contributing with their experiences and perspectives from a range of different disciplines, legal cultures and perceptions of intellectual property. The idea was to give the audience a slot during the workshop which 'rose above' the individual contributions and tried to look at the way we 'do' intellectual property research. We all 'do' this differently, of course, and the whole point of the round-table was to begin a discussion on where (and how) interdisciplinary intellectual property research finds itself on the academic map - and perhaps also where it might go in the future.

We want to thank all the participants at the 2014 workshop, and especially the contributors to this special issue and our round-table panellists for engaging with these questions in Uppsala. Your respective contributions to a self-reflexive dialogue and critical engagement with the 'the doing of interdisciplinary intellectual property work' provide important stimulus for the field's future as well as the continued activities of ISHTIP.

For our part, we hope that the ISHTIP workshop in 2014 contributed to ISHTIPs goal 'to re-frame - to broaden and deepen - current intellectual property debate', by actualizing the combined competence of the ISHTP collective to open a discussion about the inherent, interdisciplinary instability of intellectual property.

\section{Marianne Dahlén (Uppsala University) \\ Martin Fredriksson and Eva Hemmungs Wirtén (Linköping University)}

March 2015 